\title{
SH2 Domain-Containing Protein 1B
}

National Cancer Institute

\section{Source}

National Cancer Institute. SH2 Domain-Containing Protein 1B. NCI Thesaurus. Code C118226.

SH2 domain-containing protein 1B (132 aa, $15 \mathrm{kDa})$ is encoded by the human SH2D1B gene. This protein plays a role in the regulation of receptor signaling. 